\title{
Wacana Kekerasan Fisik dalam Komik Jurnalistik Footnotes in Gaza
}

\author{
Ridhani Agustama \\ Alumnus Program Studi Ilmu Komunikasi, Universitas Islam Indonesia \\ Anang Hermawan \\ Dosen Program Studi Ilmu Komunikasi, Universitas Islam Indonesia
}

\begin{abstract}
Conflict between Israel and Palestine still become the hot issue that all media covering on it. But the information flow about the conflict is dominated by Western Media. The domination followed by Western Media's effort to manipulate the information. For example, Western Media called Palestine as a dispute land; meanwhile if we look at the history it was the Israel colonized Palestine.

There are several alternative point of view about the conflict. One of the alternative point offered by Joe Sacco, an US comic writer. Sacco offers the stoires from fact that often forgotten by the Western Media. This research discuss about Footnotes in Gaza, one of Sacco's comic. Footnotes in Gaza based on Sacco's investigation about Khan Younis and Rafah incident in 1956, when the the Palestinie civilian were being killed by Israeli soldiers.

This resarch use Sara Mills' positioning the subject-object as the methods. In The Footnotes in Gaza, clearly seen that the position of the narrator (the subject) is always held by the victims (the Palestinians), while the object is the Israeli with all their act of violence.
\end{abstract}

Keywords: comic, alternative journalism, discourse analysis, physical violence, Palestine

\begin{abstract}
Abstrak
Konflik antara Israel dan Palestina masih berlangsung hingga saat ini. Konflik berusia hampir 100 tahun ini terus diberitakan oleh berbagai media. Namun begitu arus informasi mengenai konflik tersebut didominasi oleh Media Barat. Dominasi tersebut diiringi dengan upaya memanipulasi informasi oleh Media Barat.

Namun begitu tetap ada pandangan alternatif terhadap konflik tersebut. Komikus Joe Sacco, lewat sejumlah karyanya, kerap mengangkat cerita-cerita yang kerap dilupakan oleh media Barat. Penelitian ini menilik Footnotes in Gaza, buku komik karya Sacco itu merupakan hasil investigasi terhadap peristiwa pembantaian yang terjadi di Khan Younis dan Rafah, Palestina. Sacco merangkum fakta yang dia gali di lapangan, lalu diracik menjadi satu jalinan cerita komik berperspektif jurnalistik yang informatif dan mendalam.

Footnotes in Gaza sangat gamblang dalam menggambarkan kekerasan fisik tentara Israel di Palestina, khususnya pada kejadian di Raffah dan Khan Younis pada 1956. Dengan memakai metode posisi subjek-objek milik Sara Mills, terlihat jelas dalam Footnotes in Gaza, posisi pencerita (subjek) selalu dipegang oleh korban (rakyat Palestina), sementara itu yang menjadi objek adalah tentara Israel dengan segala tindak kekerasannya.
\end{abstract}

Kata Kunci: komik, jurnalisme alternatif, analisis wacana, kekerasan fisik, Palestina 


\section{Pendahuluan}

Muasal konflik tanah Palestina, antara Arab dan Israel di era modern adalah ketika Inggris mencanangkan Deklarasi Balfour pada tahun 1917. Sebuah surat perjanjian yang dikirim oleh Menteri Luar Negeri Inggris waktu itu, Sir Arthur James Balfour, kepada pimpinan komunitas Yahudi di Inggris, Lord Rothschild, dengan tembusan komunitas Zionis. Surat yang dirancang oleh kabinet Inggris pada 2 November 1917 itu menyampaikan, pemerintah Inggris merestui bangsa Yahudi untuk menempati Palestina sebagai tempat tinggalnya. Disampaikan juga sebuah catatan bahwa mereka (Yahudi) tidak boleh mengganggu penghuni asli yang sudah ada sejak zaman dahulu kala.

Pasca perang dunia II, tepatnya tahun 1948, setelah bangsa Yahudi Eropa mulai lepas dari tekanan NAZI Jerman, mereka beramai-ramai hijrah ke Palestina. Kaum Yahudi meyakini Palestina sebagai tanah yang dijanjikan, "Promised Land", seperti yang dijanjikan oleh Deklarasi Balfour. Ibarat gayung bersambut, "bedol desa" ini didukung oleh kaum Zionis, kaum ultra nasionalis Yahudi yang sejak awal menuntut kembalinya bangsa mereka ke tanah yang dijanjikan itu.

Peristiwa "bedol desa" bangsa Yahudi ke Palestina ini menimbulkan kontroversi. Secara sepihak, mereka juga memproklamirkan didirikannya negara Israel. Kontan hal ini membuat bangsa Arab yang sudah bercokol di sana sejak dulu jadi kebakaran jenggot. Tanpa tunggu lama, kedua pihak mulai angkat senjata, saling lontar timah panas. Tepat sehari setelah proklamasi negara Israel di tanggal 14 Mei 1948, meletuslah insiden Al Nakba, meski demikian peristiwa ini tidak begitu disebut khalayak.

Konflik Israel kontra Palestina hingga sekarang terus berjalan. Dari dua perang besar macam Perang Enam Hari tahun 1967 dan perang Yom Kippur tahun 1973 yang sifatnya masif, hingga konflikkonflik kecil yang tidak terhitung jumlahnya. Sejumlah peristiwa kecil juga luput dari lirikan para jurnalis. Seperti terlihat di layar kaca atau barisan kata di surat kabar, media Barat selalu bersikap samar dalam memberitidakan konflik dua tetangga ini. Senada dengan apa yang diungkap jurnalis senior asal Inggris, Robert Frisk. Israel di bawah lindungan duo Inggris dan Amerika Serikat selalu digambarkan secara abu-abu oleh media Barat (Kebohongan Elit Barat Soal Israel, Inilah.com, 2 Januari 2009).

Menurut pernyataan yang dimuat di harian Surabaya Post, Robert Frisk menyatakan, media-media barat memanipulasi informasi melalui penyesatan penggunaan kata-kata. Media Barat menyebut Palestina dalam beritaberitanya dengan tanah sengketa (disputed land). Padahal jika ditilik dari sejarah dan kenyataan yang ada sekarang, sejatinya Palestina adalah jajahan Israel (Syah, 2011). 
Beruntung sekarang mulai muncul media dari Timur, guna mengimbangi arus informasi yang selama ini dimonopoli oleh pihak Barat. Salah satu yang menonjol adalah Al Jazeera, stasiun televisi yang lahir pada tahun 2006. Televisi yang berbasis di Qatar itu menjadi penyeimbang atas arus informasi yang selama ini sifatnya searah. Hugh Miles, seorang jurnalis Inggris kelahiran Arab, berkomentar tentang hadirnya Al Jazeera, "untuk pertama kalinya dalam ratusan tahun, informasi mengalir dari Timur ke Barat.” (dalam Jafar M. Sidik, 2008)

Serupa Al Jazeera, seorang jurnalis sekaligus komikus kelahiran Malta, Joe Sacco, berusaha menyajikan sudut pandang alternatif terhadap kasus Palestina. Lewat sejumlah karyanya, Sacco mengangkat cerita-cerita yang kerap dilupakan oleh media Barat. Peristiwaperistiwa yang dikisahkannya ini menjadi penting sebab merenggut nyawa orang tidak berdosa. Berita umum melihatnya sekadar sebagai data statistik, bahkan sejarah pun ikut memarjinalkan para korban. Sacco jelas tidak ingin melupakan kepingan-kepingan peristiwa itu, oleh karenanya dia mencoba untuk mewartakannya dalam bentuk komik.

Penelitian ini akan menilik Footnotes in Gaza. Karya Sacco (2009) setebal 418 halaman itu merupakan hasil investigasi mendalam tentang peristiwa pembantaian yang terjadi di Khan Younis dan Rafah, Palestina. Pembantaian itu dilakukan oleh IDF (Israel Defense
Force), tentara Israel, terhadap 275 penduduk Khan Younis, Palestina, pada 3 November 1956. Di Raffah, kekejaman IDF termanifestasi lewat hilangnya nyawa 111 penduduk pada 12 November 1956. Meski telah lebih 50 tahun berlalu, tidak banyak pelaporan jurnalistik yang mengetengahkan peristiwa-peristiwa di atas. Karya Sacco boleh diajukan sebagai salah satu dari yang sedikit itu. Semakin menarik sebab medium penyampai warta yang dipilih Sacco adalah komik. Kartunis berusia 52 tahun itu merangkum fakta yang dia gali di lapangan lalu diracik menjadi satu jalinan cerita komik yang informatif lagi mendalam.

Komik yang selama ini oleh kebanyakan orang dianggap sebagai produk hiburan, ternyata menyimpan hal yang lebih jauh dari itu. Mengutip pernyataan Scott McCloud, "I felt that there was something lurking in comics. Something that had never been done. Some kind of hidden power" (1994: 132). Ada hal lain yang merayap keluar dari dalam komik, sesuatu yang belum pernah terpikirkan sebelumnya. Semacam kekuatan tersembunyi yang menanti untuk meletup keluar dari dalamnya. Kekuatan ini adalah imaji-imaji yang bersifat gambar atau selain-gambar yang dijajarkan dalam satu sekuens yang dengan sengaja dimaksudkan untuk mengandung informasi (McCloud, dalam Darmawan, 2012: 37).

Sacco adalah satu di antara beberapa yang konsisten menerapkan 
Jurnalisme Komik, sebuah istilah yang belakangan muncul untuk mengidentifikasi karya-karya komik yang berdasar pada investigasi mendalam terhadap sebuah peristiwa. Tentu saja, yang dilakukan Sacco itu berada di luar pakem jurnalistik yang umum kita kenal (terkhusus di Indonesia), di mana investigasi jurnalistik senantiasa menemukan bentuknya dalam tulisan di media cetak atau reportase investigasi di media elektronik.

Bentuk lain dari perkawinan jurnalisme dan komik paling banter tersaji lewat komik strip yang terdiri dari beberapa kolom saja. Di ranah jurnalistik Indonesia, komik strip pun sekadar dianggap pelengkap atau suplemen. Contohnya di surat-surat kabar kebanyakan, kita bisa menemukan kartun kecil yang isinya berupa sindiran-sindiran jenaka tentang suatu peristiwa besar yang sedang menjadi buah bibir. Karya Sacco jelas telah melangkah jauh, meninggalkan bentuk lawas perkawinan jurnalistik dan komik itu.

Ada satu definisi menarik dari kurator seni Universitas Seni Buffalo Wellesley, Massachusets, Lisa Fischman soal karya Sacco:
"Dengan
mengkombinasikan
reportase pada saksi-saksi mata dengan perspektif filosofis dan politis dari orang-orang yang ditemuinya, Sacco menceritidakan kisah-kisah dimana pengalaman- pengalaman, kenangan-kenangan dan suara-suara yang secara sistematis dikecualikan dari cakupan pemberitaan arus utama -

mereka yang dipinggirkan, dilupakan sejarah- disembuhkan." (dikutip dari "Joe Sacco", www.fantagraphics.com). Definisi tersebut tergambar jelas dalam karya-karya Sacco, yang memang fokus utamanya adalah daerah konflik, mulai dari daerah balkan sampai ke zona panas Palestina.

Praktik Sacco dalam membuat komik ini, bisa jadi merupakan bentuk dari jurnalisme alternatif. Atton dan Hamilton (2008: 1) menyebut alternative journalism sebagai, “...the media of protest groups, dissidents, fringe political organisations, even fans and hobbyists." Biasanya orang-orang ini tidak puas dengan gaya peliputan media pada umumnya, yang lebih berorientasi bisnis dan komersil. Para pelakunya menulis dan melaporkan berita dalam posisinya sebagai masyarakat, anggota komunitas bahkan sebagai aktivis atau seorang fan. Medium yang dipakai, dalam alternative journalism, bisa berupa apa pun, termasuk komik. ${ }^{1}$

Melihat tanggapan dari Lisa Fischman, serta definisi seputar jurnalisme alternatif, menjadi menarik untuk melihat wacana-wacana Sacco dalam karya-karyanya. Oleh karena itu, penulis memutuskan untuk menganalisis wacana di balik Footnotes in Gaza sebagai fokus utama penelitian ini. Untuk melakukannya, penulis akan meminjam

\footnotetext{
${ }^{1}$ Menurut Coulton Waugh, komik memiliki definisi yang mencakup tiga elemen: (1) Gambar-gambar berurutan yang menyampaikan cerita atau lelucon, (2) Balon katakata yang bekerjasama dengan gambar, dan (3) Karakter yang berkelanjutan. Lebih lengkap baca: Coulton Waugh, The Comics, (1947).
} 
pendekatan milik Sara Mills. Pendekatan ini akan dipakai sebagai pisau analisa untuk melihat penggambaran praktik kekerasan fisik di daerah konflik di dalam Footnotes in Gaza. Tema kekerasan fisik dipilih karena menjadi topik yang kerap diangkat Sacco dalam hampir setiap karyanya, termasuk di Footnotes in Gaza.

\section{Konflik Israel dan Palestina dalam Penelitian Komunikasi}

Konflik Israel dan Palestina bukan barang baru dalam penelitian komunikasi. Umumnya para peneliti mencoba membandingkan wacana milik mediamedia arus utama tentang konflik Palestina dan Israel. Jarang sekali yang mengulas bentuk-bentuk lain dalam pemberitaannya, umumnya tersentral pada teks berita surat kabar atau informasi dari media elektronik dan internet.

Dari yang tak banyak itu, penulis menemukan sebuah penelitian yang menyinggung soal karya Sacco, yaitu Representasi Praktik Alternative Journalism Joe Sacco dalam Komik Palestine (Aditya, 2012) dan Representasi Identitas Nasional dalam Komik (Analisis Semiotik Representasi Tindakan Kolektif dan Keterikatan Geografis Bangsa Palestina dalam Komik Palestine (Putranti, 2009).

Aditya maupun Putranti menganalisis Palestine, karya pertama dari Sacco, sementara penulis akan membedah Footnotes in Gaza. Palestine dikerjakan pada 1991-1993, pertama kali dirilis 1996 dan mulai menemukan tempatnya setelah diterbitkan lagi pada tahun 2001. Secara bentuk,Palestine juga terdiri dari kumpulan laporan berbentuk komik, atau yang lazim disebut antologi. Sementara Footnotes in Gaza dipublikasikan pada 2009 dan bukanlah sebuah antologi. Selain itu ada rentang waktu yang panjang dalam tahun pembuatan dan penerbitan kedua karya Sacco di atas. Tentu saja ada perbedaan dalam sosok Sacco sepanjang rentang waktu itu. Perbedaan itu bisa jadi termanifestasi dalam hal teknis maupun sudut pandangnya dalam melihat persoalan, lebih jauh lagi pada wacana yang ditawarkan.

Perbedaan selanjutnya, Aditya melakukan pembuktian dengan meminjam Piere Bourdieu, Putranti membongkar makna Palestine dengan melakukan analisis semiotika. Sementara itu, penulis menetapkan pilihan pada pendekatan analisis wacana milik Sara Mills.

Perkawinan Komik dan Jurnalistik Sebagai Wujud Jurnalisme Alternatif

Guna memahami komik maka ada beberapa pengajuan definisi yang layak diungkap. Will Eisner, maestro komik asal New York, mengungkap komik sebagai seni bertutur menggunakan gambar secara berurutan. Ini yang kelak diistilahkannya sebagai sequential art 
atau seni keberurutan. Sepuluh tahun kemudian dia memberikan makna baru terhadap komik. Eisner menuturkan bahwa komik adalah tatanan gambar dan balon kata yang berurutan dalam sebuah buku komik (Eisner, 1996). Secara keseluruhan Eisner mencoba mengungkapkan dua elemen penting dalam komik, yaitu kata dan gambar. Eisner melihat komik sebagai seni komunikasi bukan sebagai aplikasi seni.

Melalui bukunya, Understanding

Comic (1994), Scott McCloud menyebut komik adalah gambar dan lambang yang memiliki posisi berdekatan dalam satu urutan tertentu dengan tujuan memberikan suatu informasi tertentu dalam rangka mencapai satu tanggapan estetis dari pembaca.

Bila Eisner melihat letak seni dalam komik pada penyampaian pesan, maka McCloud memandang estetika kesenian itu bisa ditemukan dalam kemampuan imajinasi para pembacanya. Meski demikian, pemaparan Eisner dan McCloud jika disandingkan dapat saling melengkapi sebuah kesatuan definisi komik. Sequential art rumusan Eisner, menjadi lengkap dengan adanya tawaran definisi berupa seni imajinasi (pemberian nilai ekstetika) terhadap setiap sekuenssekuens yang hadir, seperti yang diungkap oleh McCloud. Dalam pemahaman itu komik sejak dari pembuatnya hingga pembacanya merupakan sebuah produk kesenian.
Dari pemaparan dua maestro komik di atas, bisa disebutkan dua unsur utama dalam komik adalah kata-kata tertulis dan gambar. Maka penelitian ini memfokuskan diri pada kata-kata tertulis dan gambar dalam karya Footnotes in Gaza, dan melihat layak-tidaknya karya Sacco itu disebut sebagai produk jurnalistik.

Dalam melihat proses silang jurnalistik dan komik, harus pula dilihat apakah rentetan teks dan gambar telah memenuhi kriteria-kriteria mendasar dari jurnalistik. Hal sederhana yang layak dikemukakan adalah nilai-nilai berita serta prinsip dasar $5 \mathrm{~W}+1 \mathrm{H}$.

Mari menyebut jurnalisme sebagai sebuah praktik komunikasi massa. Fajar Junaidi menjelaskan komunikasi massa sebagai komunikasi melalui media massa, yakni surat kabar, radio, televisi, internet dan sebagainya. Elizabeth-Noelle Neuman yang membedakannya dengan komunikasi interpersonal yakni bersifat tidak langsung, harus melalui media teknis; bersifat satu arah, tidak ada interaksi antarpeserta komunikasi; bersifat terbuka, ditujukan kepada publik yang tak terbatas dan anonim; dan memiliki unsur geografis yang tersebar (dalam Rahmat, 1999).

Buku sendiri adalah salah satu produk media komunikasi massa. Istilah buku komik muncul pertama kali dari terbitan pertama pada tahun 1930-an, yang ketika itu masih berupa kumpulan potongan-potongan kartun di surat kabar yang dibukukan (Vivian, 2008). Komik 
dipandang memiliki daya tarik tersendiri, karena wujudnya yang cukup unik berupa satu rangkaian gambar yang berurutan dan saling berkaitan satu dengan yang lain. Di dalam komik ada beberapa titik penting yang menjadikannya unik dibanding media komunikasi lain. Diantaranya adalah pesan-pesan yang terwujud dalam goresan pena sang komikus itu sendiri.

Mengutip definisi Hikmat Darmawan (2012), komik adalah medium komunikasi yang paling efektif. Menurutnya, disamping lebih murah dibanding medium audio-visual, komik juga efektif sebagai medium komunikasi karena sifatnya yang sekuensial. Boleh dibilang, pesan apa saja bisa disampaikan lewat bahasa komik.

\section{Kekerasan Fisik dalam Footnotes in} Gaza

Jerome Tadie (2009: 12) mendefinisikan kekerasan sebagai penggunaan kekuatan terhadap seseorang, hukum atau terhadap kebebasan publik. Dalam praktiknya penggunaan kekuatan itu bisa diterapkan pada fisis atau pun psikologis. Penelitian ini akan banyak menyoal kekerasan fisis yang termanifestasi dalam Footnotes in Gaza. Johan Galtung (seperti dikutip Windu, 1992) menjelaskan kekerasan fisis sebagai berikut:

"Dalam kekerasan fisis tubuh manusia disakiti secara jasmani bahkan sampai pada pembunuhan”.
Francoise Heritier (1996) menjelaskan pendapatnya soal kekerasan: "Perusakan terhadap tubuh yang dipahami sebagai kawasan tertutup, atau terhadap kawasan fisik atau moral yang dipahami sebagai satu tubuh yang dapat dipilah-pilah.” Praktik kekerasan ini berlaku, baik yang dilakukan secara personal, kelompok maupun stuktural.

Galtung membedakan kekerasan personal dan struktural. Kekerasan struktural sifatnya statis, memperlihatkan stabilitas tertentu dan tidak tampak. Kekerasan personal bertitik berat pada "realisasi jasmani aktual". Ada tiga pendekatan untuk melihat kekerasan personal yaitu cara-cara yang digunakan (menggunakan badan manusia atau senjata), bentuk organisasi (individu, massa atau pasukan) (dalam Windu, 1992).

Dalam kasus Palestina dan Israel, koridor kekerasan tidak lagi datang dari hal-hal personal, tapi juga hadir dalam bentuk struktural dan sistematis. Kasus Palestina dan Israel, menjadi lebih kompleks, sebab ada dua negara yang mendiami satu wilayah, sebagai muasal konflik, perebutan ruang di antara keduanya lah yang melahirkan kekerasan. Negara (dalam hal ini Israel) telah muncul sebagai alat kekerasan. Apa saja instrumen kekerasan? Para pemikir beraliran Marxis menyebut alat-alat kekerasan itu bisa termanifestasi dalam tubuh militer, hukum, penjara dan istrumen lainnya. 


\section{Metodologi Penelitian}

Penelitian ini merupakan sebuah penelitian deskriptif kualitatif. Penelitian deskriptif lebih menjurus pada hal-hal spesifik. Dalam penelitian ini penulis menganalisis wacana di balik praktik kekerasan fisis dalam komik Footnotes in Gaza. Metode kualitatif bertujuan untuk menjelaskan sedalam mungkin sebuah fenomena sosial dengan pengumpulan data sedalam-dalamnya. Riset model ini tidak mengutamakan besarnya populasi dan sampling (Kriyantono, 2004).

Ada empat sub judul yang dipilih dalam penelitian ini. Keempat itu adalah: Sea Street (hal. 208-224), School Wall (hal. 225-230), School Gate (hal. 231244), dan The Search (hal. 269-281). Alasan dipilihnya keempat sub judul ini adalah karena keunikan yang terdapat dalam masing-masing sub judul yang masing-masing bercerita perihal kekerasan lewat sudut pandang yang berbeda. Mulai dari kesaksian seorang guru, anak kecil hingga perempuan yang berprofesi sebagai ibu rumah tangga.

Paradigma penelitian yang digunakan adalah paradigma kritis, sebuah pendekatan yang bertujuan untuk memperjuangkan ide penulis agar bisa membawa diskursus yang lebih jauh pada khalayak. Dalam hal ini tentunya penulis ingin melihat wacana di balik penggambaran praktik kekerasan fisis dalam Footnotes in Gaza, sebagai sebuah produk jurnalisme komik. Oleh karenanya penulis akan mengambil sekuens-sekuens dalam komik Footnotes in Gaza untuk menganalisis penggambaran praktik kekerasan fisis di tanah Palestina. Paradigma ini akan berdekatan dengan critical theory (teori kritis) yaitu suatu wacana atau cara pandang terhadap realitas yang mempunyai orientasi ideologis tertentu.

Penelitian ini akan bertopang pada teori analisis wacana yang dikemukakan oleh Sara Mills. Secara umum, ada dua penekanan dalam metode Sara Mills yakni posisi subjek-objek dan posisi pembaca. Dalam posisisubjek-objek, representasi menjadi poin penting dalam hal ini, seperti halnya analisis wacana lainnya. Bagaimana satu pihak, kelompok, orang, gagasan, atau peristiwa ditampilkan dengan cara tertentu dalam wacana berita yang mempengaruhi pemaknaan. Wacana media pada posisi ini dipandang sebagai sesuatu yang tidak netral, karena cenderung menempatkan aktor tertentu sebagai subjek yang mendefinisikan peristiwa atau kelompok tertentu. Posisi subjek inilah yang menentukan semua bangunan unsur teks. Sementara dalam posisi pembaca, menurut Mills, teks adalah suatu hasil negosiasi antara penulis dan pembaca. Konteks dan latar belakang pembaca harus pula diperhatikan saat dia berinteraksi dengan teks, tidak semata melihat konteks dari si penulis (dalam Eriyanto, 2006).

Selain metode analisis wacana kritis Sara Mills, penelitian ini akan meminjam teori Atton dan Hamilton (2008), 
terutama tentang ciri jurnalisme alternatif, yakni meninjau kembali objektivitas, representasi suatu kaum dan saksi mata yang aktif, narasumber, dan krealibilitas dan kreadibilitas pewarta

Ada pun data primer dari penelitian ini adalah komik Footnotes in Gaza karya Joe Sacco (Metropolitan Books, New York, 2009).Ada pun data sekunder berupa hasil wawancara media massa atau jurnalis lainnya dengan Joe Sacco atau tulisan-tulisan lain seputar Sacco dan Footnotes in Gaza.

\section{Hasil dan Pembahasan: Analisis Wacana Kritis terhadap Footnotes in Gaza}

Penulis akan memakai analisis Sara Mills dalam melihat wacana seputar kekerasan fisik yang disajikan oleh Sacco dalam karyanya Footnotes in Gaza. Penulis juga akan melihat representasi jurnalisme alternatif dalam Footnotes in Gaza, yang dilihat berdasar ciri-ciri jurnalisme alternatif yang diungkapkan oleh Atton dan Hamilton (2008).

\section{Posisi Subjek-Objek}

Hal terpenting yang harus dicatat, dalam Footnotes in Gaza, hampir setiap cerita merupakan hasil wawancara Sacco terhadap saksi mata atau korban. Sehingga pandangan yang selalu dilihat dalam karya ini adalah posisi subjek (saksi mata atau korban) yang bercerita tentang objek (tentara Israel). Para subjek umumnya menggambarkan posisi mereka sebagai orang yang menjadi korban. Objek utamanya adalah tentara Israel, yang digambarkan kejam dan penuh kekerasan. Itu terekam dalam kesaksian-kesaksian yang dikutip Sacco. Dari berbagai pemaparan subjek (korban) yang dimuat dalam Footnotes in Gaza, terlihat jelas bahwa Sacco berusaha meramu kesaksian menjadi alur dan laporan yang menarik, serta layak diketahui khalayak.

Patut juga dicatat subjek (korban) memiliki otoritas penuh di atas pena Sacco, sehingga posisi mereka paling mungkin mempengaruhi pencitraan subjek (tentara Israel). Terlebih dengan posisi Sacco, yang memang ingin menyuarakan kepentingan korban. Ratarata subjek (korban) menggambarkan kondisi mereka kala itu yang sangat tertekan, terutama dibawah ancaman kekerasan dari tentara Israel.

Sacco menampilkan posisi subjek yang terlihat tidak berdaya, hal ini dilihat lewat pengakuan macam posisi mengangkat tangan, sebagai tanda menyerah. Atau di lain kesempatan meminjam sosok anak kecil sebagai korban sehingga menimbulkan empati. Di satu ketika juga menempatkan perempuan untuk menjadi penutur. Ini penting untuk melihat masalah kekerasan ini di mata perempuan.

\section{Posisi Pembaca}

Negosiasi antara Sacco dengan pembaca juga menarik dilihat misal ketika ia memilih menempatkan seorang guru 
sebagai penutur utama di salah satu sub judul. Beberapa kali juga Sacoo menonjolkan saksi yang ketika kejadian masih berusia anak-anak pun bisa dipastikan akan menarik perhatian pembaca, dan mengajak mereka untuk berempati. Rasa kemanusiaan pembaca tegugah sebab anak-anak memiliki karakter yang polos dan tidak memiliki kaitan langsung dengan perang. Di sinilah Sacco mengundang perhatian pembacanya, nalar kemanusiaan pembaca diajak merasakan pilunya perasaan korban yang polos dan tak punya kepentingan langsung dengan perang yaitu anak-anak. Di waktu lain juga muncul kesaksian dari kaum perempuan.

Meski demikian, mari menganggap proses pertukaran wacana ini sebagai sebuah negosiasi. Dalam hal ini Sacco sedang menawarkan wacana miliknya kepada para pembaca. Perlu pula dicatat bahwa pembaca memiliki sejumlah latar belakang yang juga perlu diperhatikan. Latar belakang itu akan menentukan sikap dan cara pandang mereka terhadap karya ini (atau proses negosiasi).

Saat karya Sacco dinikmati oleh pembaca, ada beberapa kemungkinan yang akan terjadi. Pertama, bagi pembaca yang bersandar pada nilai kemanusiaan. Pembaca yang oleh Sacco diajak untuk berposisi seperti para korban di atas, tentu akan melihat nilai-nilai yang melekat pada korban pada saat bersamaan juga ada pada diri mereka sehingga sentimen kemanusiaan mereka akan tergugah sedemikian rupa.

Jenis latar belakang pembaca yang kedua adalah mereka yang selama ini berpendapat bahwa konflik IsraelPalestina merupakan konflik agama. Mereka akan kesulitan mendapatkan representasi agama di karya Sacco. Hal itu disebabkan oleh posisi Sacco yang melihat agama sekedar elemen kultural yang mempengaruhi masyarakat, bukan sebagai simbol pemicu perang. Mereka yang menganggap konflik Israel-Palestina dipicu oleh agama, tentu akan mencari jalan untuk mendukung latar belakang ideologisnya itu. Paling banter mereka hanya akan menyebut soal ada orang yang memakai surban atau pakaian panjang ala Islam yang memang menjadi korban.

Sacco memang menggambarkan pakaian panjang atau surban, tapi itu lebih sebagai citra kultural. Artinya, agama dipandang Sacco sebagai bagian dari kebudayaan, sekaligus memungkinkannya (agama) mempengaruhi pola dan gaya hidup di dalam masyarakat. Tak satu pun argumen para subjek (korban) yang secara tegas menyebut bahwa bangsa Palestina kala itu disikat karena sebagian besar mereka adalah muslim. Dalam beberapa kesempatan mereka memang menyebut kata semacam Jews (Yahudi) atau Jews Soldier (tentara Yahudi). Tapi makna kata itu lebih pada soal citra kebudayaan, yang membuat mereka berbeda, bukan sebagai satu-satunya alasan mereka kena bantai. 
Ketiga adalah pembaca yang selama ini mendapatkan arus informasi dari media-media arus utama, terutama yang banyak disebar di masyarakat barat, macam CNN. Seperti sudah disinggung sebelumnya (di awal karya) banyak media barat yang memberitakan konflik IsraelPalestina dengan cara-cara yang tidak berimbang sehingga kerap kali kekerasan yang terjadi pun dipahami setengahsetengah. Pembaca dengan latar belakang ini akan sangat kritis terhadap karya Sacco. Terlebih apa yang diceritakan Sacco ini memang jarang diungkap oleh media arus utama. Bahkan belakangan cenderung dilupakan karena rentang waktunya yang sudah lama berlalu. Laporan resmi PBB pun seolah membuka ruang bahwa kejadian ini lumrah terjadi, karena kepanikan massal. Media-media barat pun hanya menempatkannya sebagai catatan kaki. Maka para pembaca setia saluran informasi resmi di Barat akan memberi pertanyaan seputar signifikansi kisah Sacco ini. Hal terburuk, boleh jadi mereka akan melihat Sacco terlalu melebih-lebihkan.

Meski demikan, kalangan pembaca utama saluran komunikasi di Barat akan diuntungkan sebab Sacco sempat mewawancarai seseorang yang kesaksiannya belum tentu bisa dipercaya. Sacco mungkin ingin menekankan posisinya sebagai seorang jurnalis ketika memasukkan kesaksian ini ke dalam cerita. Sebab dia sendiri menyatakan bahwa dirinya skeptis dan setengah tidak percaya dengan cerita ini. Sebagai jurnalis ini sikap yang memang diperlukan. Tapi dengan memasukkan cerita itu, mereka yang percaya dengan narasi-narasi dari media Barat, akan membuat kesimpulan sendiri: bahwa tak semua keterangan dari subjek (korban) bisa dipercaya. Boleh jadi para pembaca utama saluran komunikasi di Barat akan menjadikan itu sebagai contoh kasus tak masuk akal di sub judul Sea Street itu, sebagai sampel pernyataan yang berlebihan.

Selain itu, cerita seputar fedayen, juga kurang dikemukakan oleh Sacco. Padahal titik ini yang sering jadi bahan pembenaran dalam operasi screening. Sehingga bisa menjadi bahan serangan dengan menyebutnya berat sebelah dalam membuat laporan.

\section{Representasi Jurnalisme Alternatif dalam Footnotes in Gaza}

Di bagian ini penulis akan coba melihat representasi jurnalisme alternatif dalam karya Sacco tersebut. Untuk itu, penulis akan meminjam ciri jurnalisme alternatif yang diungkap oleh Chris Atton dan James Hamilton.

\section{Meninjau kembali Objektivitas}

Atton dan Hamilton menjelaskan dalam bagian ini, pentingnya jurnalisme untuk meninjau kembali objektivitas. Menekankan sisi-sisi humanis dalam pemberitaan serta mengumpulkan faktafakta yang kerap dilewatkan oleh media arus utama. 
Pertanyaan lanjutan yang mungkin saja muncul: Benarkah kekerasan itu hanya menelan 111 korban jiwa di Raffah? Sebab penggambaran saksi dalam Footnotes in Gaza melukiskan bahwa korban yang mati bisa saja lebih dari angka resmi itu. Berkali-kali ditemukan gambar Sacco yang menampilkan sosok tubuh tak bernyawa, bahkan bertumpuktumpuk. Artinya, Sacco sedang mengajak orang untuk mempertimbangkan kebenaran jumlah korban di Raffah versi PBB.

Judul Footnotes in Gaza ini pun mendapatkan tempat sebagai pernyataan satir. Sebab jika melihat gambaran Sacco di Footnotes in Gaza, tragedi Raffah dan Khan Younis seharusnya tak lagi dijadikan sekedar catatan kaki, seperti yang selama ini dilakukan oleh media Barat. Objektivitas yang ditawarkan Sacco dalam Footnotes in Gaza adalah bentuk yang harus dicari, bukan sekedar diterima mentah-mentah. Itu yang membuatnya terus melakukan penelusuran, ketimbang mempercayai jejak yang sudah diceritakan oleh laporan-laporan resmi.

Di lain sisi, kita juga kerap terjebak pada pertanyaan filsafat: apa itu objektivitas? Kovach dan Rosenstiel (2006) mengungkap bahwa objektivitas bukanlah tujuan utama jurnalisme, tapi objektifitas adalah sesuatu yang harus terus dicari dan dilengkapi.

\section{Representasi suatu kaum dan}

\section{saksi mata yang aktif}

Apa yang direpresentasikan oleh Footnotes in Gaza? Karya ini merupakan sebuah kolase ingatan dari para korban tragedi Raffah dan Khan Younis di tahun 1956. Maka representasi cerita ini adalah para saksi mata yang aktif dari peritiwa tersebut. Atton dan Hamilton berpendapat, idealnya saksi mata aktif kerap ditemukan dalam jurnalisme di era pergerakan sosial baru, dimana testimoni subjektif dan saksi mata adalah hal yang dominan dalam reportase, dan subjek menceritakan dirinya sendiri (Atton \& Hamilton, 2008:87). Hal semacam ini kerap muncul sebagai tandingan kepada media-media arus utama, yang kadang hanya menjadi representasi dari para pemilik atau orang-orang yang bisa mengaksesnya.

Selanjutnya setiap sub judul (yang diteliti) dinarasikan oleh banyak saksi mata, paling tidak lebih dari 5 orang. Ini menunjukkan bahwa Sacco berusaha keras untuk menggali banyak informasi. Tak jarang pula dia mengkonfrontir pernyataan para saksi mata soal kejadian.

\section{Narasumber}

Ketika media arus-utama memilih untuk mendahulukan kelompok elit sebagai narasumber, maka jurnalisme alternatif membuka akses yang luas kepada lebih banyak orang (Hamilton, 2008:90). Sulit membayangkan kesaksian para saksi ini akan dimuat oleh media- 
media arus-utama terutama di Barat. Mereka akan memilih orang-orang yang dianggap "pantas" untuk berbicara.

\section{Kredibilitas Pewarta}

Poin ini menyangkut tingkat kepercayaan khalayak kepada si pewarta. Sebagai pewarta cum komikus, dia telah membuat banyak karya terkait daerah konflik, seperti Palestine dan beberapa karyanya tentang konflik Balkan. Sehingga dia memang telah terbiasa, sekaligus dikenal sebagai seorang yang konsisten dalam mempraktikan jurnalisme komik.

Lantas apa alasan Sacco membuat karya ini? Satu-satunya yang paling masuk akal adalah rasa kemanusiaan. Dan hal ini terasa dalam sub judul yang dijadikan bahan penelitian ini. Rasa kemanusiaan lah yang sedang digugah oleh Sacco. Dia mengajak orang bersimpati melalui humanisme.

\section{Kesimpulan}

Footnotes in Gaza terbilang berhasil dalam menampilkan representasi kekerasan fisik Tentara Israel di Palestina. Terkait hal ini, pola wawancara dan riset mendalam, yang dilakukan Sacco, berkait erat dengan prinsip-prinsip kerja jurnalistik. Demi mendapatkan cerita yang utuh tentang peristiwa kekerasan ini, Sacco menceritakannya dengan membagi peristiwa dalam detail-detail lewat beberapa sub judul, seperti: Sea Street, School Wall, School Gate, The Search dan lain sebagainya. Ini juga mempermudah pembaca untuk mendapatkan gambaran (atau representasi kekerasan) yang terjadi di Raffah dan Khan Younis.

Guratan pensil Sacco, memperkuat representasi kekerasan. Guratannya yang bernuansa realis, ditambah lagi dengan kepiawaiannya mencari detail dalam setiap kesaksian membuatnya mampu membangun suasana dalam rentetan peristiwa kekerasan di tahun 1948 tersebut.

Dengan media komik, melihat karya Sacco (Footnote in Gaza) kita seolah sedang menyaksikan metode dokumentasi yang selama ini lebih banyak ditawarkan oleh film dokumenter. Seperti prinsip dalam dokumenter, maka sebisa mungkin Sacco tidak menambah atau mengurangi kesaksian para saksi terkait kekerasan Israel di Raffah dan Khan Younis.

Dengan memakai metode posisi subjek-objek milik Sara Mills, terlihat jelas dalam Footnotes in Gaza, posisi pencerita (subjek) selalu dipegang oleh korban (rakyat Palestina), sementara itu yang menjadi objek adalah tentara Israel dengan segala tindak kekerasannya. Tak heran bila posisi subjek (pencerita) selaku korban terkesan tidak berdaya, teraniaya, dan inferior. Sebaliknya, posisi objek (tentara Israel) terkesan adidaya, maha kuasa, dan superior terhadap korban. Relasi semacam ini tentu saja bukan relasi yang setara, tapi menampilkan kuasa atau penjajahan satu kaum atas yang lainnya. Di mata subjek (korban), objek (tentara 
Israel) adalah para penguasa sekaligus penjajah.

Dengan meminjam kacamata para korban, tak heran bila Footnotes in Gaza, terasa berpihak kepada mereka (korban). Mereka (korban) yang selama ini kesulitan untuk mendapatkan tempat dalam memberikan kesaksian mendapat tempat di Footnotes in Gaza.

Dengan menggunakan poin posisi pembaca dari Sara Mills, terlihat jelas bahwa Sacco ingin memposisikan pembacanya untuk berempati dengan para korban dalam tragedi Raffah dan Khan Younis. Atau dengan kata lain, Sacco mengajukan ideologi kemanusiaan yang diyakininyadengan menyentuh nilai-nilai utama bahwa kejadian di Raffah dan Khan Younis sungguh berada di luar nilai-nilai kemanusiaan. Meski demikian, menimbang silang sengkarut ideologi yang muncul di balik konflik Palestina, mungkin saja pembaca dengan beragam latar belakang memiliki tanggapan, respon atau pendapat yang berbeda, sesuai latar belakang ideologi dan pemahamannya seputar konflik tersebut.

Selain dua kesimpulan utama tersebut, penulis juga merasa perlu untuk mengemukakakan beberapa poin lain yang layak dijadikan catatan tersendiri. Poin-poin ini ditemukan setelah penulis menelaah Footnotes in Gaza selama proses penelitian. Berikut ini poin-poin catatan penting tersebut:

1. Footnotes in Gaza, merupakan sebuah karya yang muncul dengan landasan ideologi kemanusiaan dari seorang Sacco. Posisi ideologis ini yang lantas mempengaruhinya dalam membuat produk jurnalistik komik setebal 418 halaman itu.

2. Footnotes in Gaza telah memenuhi persyaratan sebagai sebuah bentuk jurnalisme komik. Sebab apa yang digambar dan dituliskan oleh Sacco telah melalui sebuah proses panjang peliputan di tanah Palestina, aspekaspek macam $5 \mathrm{~W}+1 \mathrm{H}$, independensi sebagai pewarta, dan disiplin verifikasi melakukan pelaporan.

3. Kelemahan utama dalam Footnotes in Gaza adalah terutama dalam usaha menyeimbangkan wacana dengan cover both side, sebab tidak ditemukan suara aktor lain dalam peristiwa Raffah dan Khan Younis, semuanya berkisar pada kesaksian korban. Selain itu tak ada juga suara orang beken, yang memang kerap jadi sumber utama dalam pelaporan khas media arus utama. Namun kelemahan Sacco (pada point no.2), justru bisa menjadi kekuatan serta pembedanya dengan model pemberitaan media arus utama. Dalam hal ini Sacco juga mempraktikkan jurnalisme alternatif, atau sesuatu yang justru berbeda dengan narasi jurnalisme arus utama.

4. Jurnalisme alternatif yang dipraktikan Sacco terlihat jelas lewat beberapa hal. Pertama adalah keinginannya untuk meninjau objektivitas di seputar tragedi Raffah dan Khan Younis, di 
mana persoalan ini memang jarang dipercakapkan. Kedua adalah pemilihan narasumber, yang kerap dilupakan oleh media arus utama, dan posisi mereka sebagai saksi mata yang aktif. Ketiga ialah posisinya sebagai pewarta, yang juga sekaligus meyakinkan korban untuk memberi kesaksian. Di sini Sacco juga bisa sekaligus disebut sebagai seorang aktivis kemanusiaan. Secara umum hal ini setaraf dengan empat poin ciri jurnalisme alternatif yang diungkapkan oleh Atton dan Hamilton.

\section{Keterbatasan Penelitian}

Secara umum keterbatasan utama dalam penelitian ini adalah sumber perbandingan terhadap kasus Raffah dan Khan Younis. Sejauh ini tak ada dokumen yang secara spesifik menulis tentang kasus ini. Satu-satunya dokumen yang memuat kasus ini dan dapat diakses oleh peneliti adalah laporan UNRWA. Di luar itu perhatian para peneliti jarang diarahkan ke Raffah dan Khan Younis. Mereka lebih suka untuk membahas masalah konflik Israel- Palestina di masa sekarang.

Keterbatasan lain adalah soal kurangnya referensi seputar jurnalisme komik. Sehingga referensi yang kerap dipakai oleh penulis adalah literasi yang memang kerap ditemukan dalam membahas praktik jurnalisme. Tak hanya soal literasi seputar jurnalisme komik, tapi praktik ini memang jarang dimplementasikan oleh komikus, terlebih di Indonesia. Padahal, jika ditemukan sebuah komik yang menerapkan model jurnalisme komik maka kekayaan pembahasan dalam penelitian ini bisa bergerak menjadi sebuah perbandingan antara dua karya.

\section{Daftar Pustaka}

Aditya, Hendy. 2012.Representasi Praktik Alternative Journalism Joe Sacco dalam Komik Palestine. Skripsi. Program Studi Ilmu Komunikasi di Universitas Atmajaya, Yogyakarta,.

Atton, Chris,\& James F. Hamilton. 2008.Alternative Journalism. London: SAGE Publication

Darmawan Hikmat. 2012.How To Make Comic: Menurut Para Master Komik Dunia. Yogyakarta: Plotpoint Publishing.

Eisner, Will. 1996.Graphic Storytelling and Visual Narrative, Florida: Poorhouse Press.
Eriyanto. 2006.Analisis Wacana Pengantar Analisis Teks Media. Yogyakarta: LKIS.

Heritier, Francois. 1996.De la Violence. Paris: Odille Jacob.

Kovach, Bill,\& Tom Rosensthiel. 2006. Sembilan Elemen Jurnalisme, Jakarta: Yayasan Pantau.

Kriyantono, Rachmat. 2004.Teknik Praktis Riset Komunikasi. Jakarta: Bumi Aksara.

McCloud,Scott. 1994.Understanding Comic. New York: HarperPerennial. 
Putranti, Fidiah. 2009.Representasi Identitas Nasional dalam Komik: Analisis Semiotik Representasi Tindakan Kolektif dan Keterikatan Geografis Bangsa Palestina dalam Komik Palestine. Skripsi.Fakultas Ilmu Sosial dan Ilmu Politik Universitas Gadjah Mada, Yogyakarta,.

Rahmat, Jalaludin. 1999.Psikologi Komunikasi, Rev. Ed. Bandung: Remaja Rosdakarya.

Sacco, Joe. 2009. Footnotes in Gaza. New York: Metropolitan Books.

Sidik, Jafar M. Resensi Buku: Al-Jazeera Menentang Dunia. Antara, 13 Maret 2008.

http://www.antaranews.com/berita \96373/resensi-buku-al-jazeeramenantang-dunia,diakses tanggal 1 Januari 2013

Syah, Sirikit. 2011Immersion Journalism, http://indonesianmediawatch.word press.com/2011/07/11/immersionjournalism/ (diakses tanggal 28 Oktober 2012)

Tadie, Jerome. 2009.Wilayah Kekerasan Jakarta. Jakarta: Massup Jakarta.

Vivian, John. 2008. Teori Komunikasi Massa, Rev. Ed., Jakarta: Kencana.

Waugh, Coulton. 1947.The Comics. Oford: University of Mississipi.

Windhu, I.Marsana. 1992.Kekuasaan \& Kekerasan Menurut Johan Galtung, Yogyakarta: Kanisius.

\section{Artikel dan Bahan Lainnya}

"Artist Bio - Joe Sacco", http://www.fantagraphics.com/inde x.php?option $=$ com content\&task $=\mathrm{v}$ iew\&id=267\&Itemid=82, (diakses tanggal 2 April 2013).

"Discourse", htp://www.merriamwebster.com/dictionary/discourse (diakses 1 April 2013).
"Eyeless in Gaza", http://www.guardian.co.uk/books/2 oo9/nov/22/joe-sacco-interviewrachel-cooke, (diakses tanggal 20 Januari 2013).

"Fedayen",

http://www.jewishvirtuallibrary.org /jsource/Terrorism/Fedayeen.html (diakes tanggal 30 April 2013).

"I do comics, not graphic novels", http://www.guardian.co.uk/books/2 o03/oct/23/comics.politics, (diakses 3 April 2013).

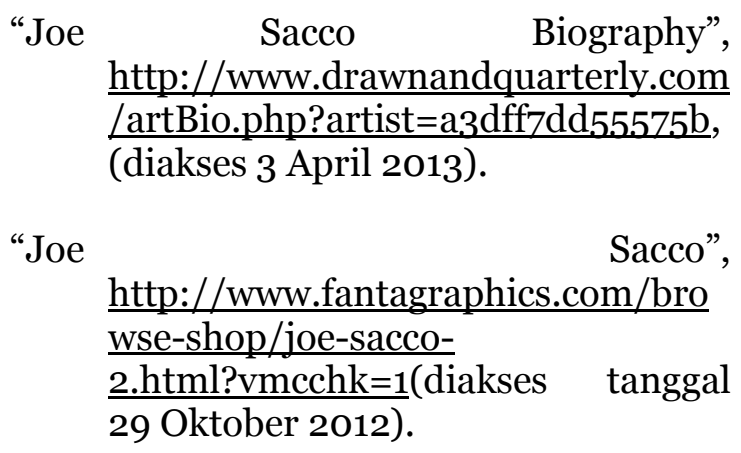

"Joe Sacco on Palestine", http://www.aljazeera.com/news/mi ddleeast/2007/11/20085251850426 79346.html (diakses 1 April 2013).

"Telephone interview with Joe Sacco", http://www.bbc.co.uk/dna/collectiv e/A2948123 (diakses tanggal 1 April 2013).

"The Palestine Mandate", http://avalon.law.yale.edu/2oth ce ntury/palmanda.asp (diakses tanggal 28 Mei 2013)

"The Principles of The Muslim Brotherhood", http://www.ikhwanweb.com/article. php?id=813 (diakses tanggal $28 \mathrm{Mei}$ 2013).

"Kebohongan Elit Barat Soal Israel". Inilah.com, 2 Januari 2009. http://web.inilah.com/read/detail/72902 kebohongan-elit-barat-soalisrael\#.UjHnBgJgdGQ, diakses tanggal 20 September 2012) 